\title{
A Letter of Condolences
}

To late Professor Jung Soon Shin,

Sir, we always felt that you would be with us as our mentor to the end. Now that you have suddenly left us, it seems as though our world is caving in and the sky is falling down. Why did you depart your loving family and your disciples so soon?

You were a great support to us in this world, but as now you have left for heaven, we, with broken heartedness, are offering this letter to your spirit.

Till your last breath, you have personally lived a life respected by all. With continuing passion, you have led us to challenge and pioneer for the development of our society and devoted your entire life to serve people with disabilities. You have also led us into a new world, a better world, and showed us what justice is as well as the right way of life. One day you taught us with strict discipline and another day with silent self-practice.

You have concentrated all your strength to establish the Korean Academy of Rehabilitation Medicine in 1971, and found the Journal of Rehabilitation Medicine, when the field of Rehabilitation Medicine was an unexplored field in this country. Thereafter, you have been busy to adopt the Rehabilitation Medicine specialist system, and have made it possible to produce Rehabilitation Medicine specialists in 1983 for the first time. Now more than 1,500 Rehabilitation Medicine specialists are guarding the health of people with disabilities as well as that of the public. Due to the poor early financial state of the Korean Academy of Rehabilitation Medicine, you made a donation and also encouraged the directors of the academy to participate in such act. From your frugal efforts, the Korean Academy of Rehabilitation Medicine has now grown as a world class academy on the foundation of sound financial capability.

When the 4th World Congress of the International Society of Physical and Rehabilitation Medicine was held in Seoul in 2007 and all the members from the world praised it as the most successful and unprecedented congress in history, you, as an honorary president of congress, appeared so happy, and that memory is still fresh among us.

You have developed the field of Rehabilitation Medicine with tireless passion. There are no specialists in the Rehabilitation Medicine field who have not in some way benefitted from your involvement, such as physical therapists, occupational therapists, speech therapists, prosthetist and orthotist, rehabilitation psychologists and rehabilitation social workers. You have also greatly contributed to the establishment and growth of the Korean Society of Rehabilitation of Persons with Disabilities through difficult times.

For all these reasons, the people praise you as the "Godfather of the Rehabilitation field."

I remember, when I was working with you in 1983, you were writing hundreds of English letters in that small room, to send them to developed countries in order to get loans to build the Yonsei Rehabilitation Hospital. With that effort, you made it possible to receive the German KfW loan, with which the first university rehabilitation hospital was built in Korea in May 1987, which has been the epicenter of the development of Rehabilitation Medicine in Korea. You established the Department of Rehabilitation Medicine of Yonsei University in 1983 and produced numerous people of ability, who are all working as sincere and exemplary Rehabilitation Medicine specialist throughout the country.

Your residents, whom you have trained with much discipline, are welcomed anywhere in the world as the best specialists.

We know very well that you have a warm heart, although you were very strict with regard to work. Your great fondness for the people with disabilities have driven you to a higher plane of devotion. Your warm heart began with your 
love for art at a very young age. We are all aware of and cherish the story that you were awarded as the youngest winner of the Korean Painting Exhibition when you were in middle school, with newspaper clippings to prove this. As you were good at calligraphy and writing skills, many people asked to you to write important addresses or articles, and whenever you received such requests, you did not disappoint those who asked for your talent.

You also have devoted your whole life to the development of the Korean Society for the Cerebral Palsied. Can you see the number of people with disabilities who are laying flowers and feeling your absence in their hearts? We can see you smile and hear you say, "Yes, live life to the fullest" from above. Your passion for Civitan, a charity organization for children with disabilities, was also enormous.

When you were awarded with the Order of Civil Merit, Moran-Jang in recognition of your services in April 2013, how pleased were all the people with disabilities and the members of Korean Academy of Rehabilitation Medicine?

You are a true server of this age and a Great Stone Face for all of us.

After your departure, our hearts are broken, and we feel that our own strength has left with you. However, your voice still echoes in our minds. We hear, "What are you doing? There is no time for sadness. If you have such a time, go study, serve and work."

Sir, while you may be gone in body, the lessons and wisdom you have shared remain with us. To the end of our individual lives, we will follow the way you have shown us.

May you rest in peace.

With sincere gratitude and sorrow,

August 12, 2013

Chang-il Park,

The 4th President of International Society of

Rehabilitation Medicine 